\title{
ВПЛИВ РІЗНИХ МОДЕЛЕЙ ІММОБІЛІЗАЦІЙНОГО СТРЕСУ НА МОРФОЛОГІЧНІ ЗМІНИ У СЕРЦІ ВИСОКО- І НИЗЬКОСТІЙКИХ ДО ГОСТРОї ГІПОКСІЙНОї ГІПОКСІї ЩУРІВ PIЗHOÏ CTATI
}

\author{
๑О. В. Денефіль, Ю. М. Ординський, 3. М. Небесна \\ Тернопільський національний медичний університет імені І. Я. Горбачевського МОЗ України
}

PЕЗЮМЕ. Стреси трапляються у нашому житті щоденно. На один і той самий стрес кожна людина реагує порізному й не задумується про його наслідки для організму. Часто ми не враховуємо пошкоджувальної дії стресу на різні органи, зокрема на серцево-судинну систему. Визначення механізму пошкоджувального впливу стресу на серце в осіб з різною реактивністю може сприяти розробці індивідуальних методів профілактики та корекції.

Мета - визначити вплив різних режимів іммобілізаційного стресу на морфологічні зміни у серці щурів різної статі з високою і низькою стійкістю до гіпоксії.

Матеріал і методи. Досліди виконано на 96 високо- і низькостійких до гіпоксії щурах лінії Вістар віком 5,56 місяців. Тварин поділили на контрольні та дослідні групи (які зазнали іммобілізаційного стресу). Стрес моделювали шляхом чотириразової одногодинної іммобілізації щурів спинкою донизу з інтервалом у 24 години (стрес 1) і 72 години (стрес 2) між окремими стресовими епізодами. Дослідження проводили через 24 години після останньої іммобілізації.

Результати. При світлооптичному дослідженні поперечних зрізів сердець у всіх досліджуваних групах тварин, які зазнали впливу іммобілізаційного стресу, спостерігали незначні пошкодження міокарда, ступінь яких залежав від статі та моделі іммобілізаційного стресу. В усіх групах тварин виявлено помірний набряк як кардіоміоцитів, так і строми, різний ступінь некробіозу кардіоміоцитів та порушення мікроциркуляції. При стресі 1, порівняно із стресом 2, ступінь ураження міокарда був меншим. У ВГ тварин, порівняно з НГ, пошкодження були виражені слабше. Найбільші зміни відбулися при обох видах стресу у низькостійких до гіпоксії самців.

Висновок. Інтервальна іммобілізація щурів призводить до порушення морфологічної структури міокарда, ступінь розвитку якого залежить від стійкості тварини до гіпоксії, статі та моделі стресу. Найбільше пошкодження відмічено при обох видах стресу в низькостійких до гіпоксії самців.

ключовІ словА: стрес; щури; резистентність до гіпоксії; серце; морфологічні зміни.

Вступ. Реактивність організму залежить від типу вищої нервової діяльності [1], регуляторних впливів з боку автономної нервової [2], ендокринної [3] та імунної систем [4], статі [5], віку [6], умов навколишнього середовища [7] тощо. Одним із факторів, при якому змінюється реактивність, $\epsilon$ стрес. Механізми реагування на стрес $\epsilon$ універсальними, а переважання ураження чи захисту залежить від індивідуальної реактивності організму [8].

Основним у розвитку більшості пошкоджень $\epsilon$ відповідь організму на гіпоксію. Вона $\epsilon$ центральною ознакою багатьох поширених захворювань людини [9]. У загальній популяції кожного біологічного виду тварин $\epsilon$ особини з різною стійкістю до гіпоксії [8]. Дослідження особливостей пошкоджувального впливу стресу на серце при різній чутливості до гіпоксії може бути базовим для розробки індивідуальних методів профілактики і лікування.

Мета - визначити вплив різних режимів іммобілізаційного стресу на морфологічні зміни у серці щурів різної статі з високою і низькою стійкістю до гіпоксії.

Матеріал і методи дослідження. Досліди виконано на 96 високостійких (ВГ) і низькостійких до гіпоксії (НГ) щурах лінії Вістар віком 5,5-6 місяців. Тварин поділили на групи - контрольні та дослідні, які зазнали різних моделей іммобілізаційного стресу. У кожній з груп було по 12 самців і 12 самиць. Виділення із загальної когорти тварин особин з різною стійкістю до гіпоксії проводили за методикою В. Я. Березовського (1978) [10]. Стрес моделювали шляхом чотириразової одногодинної іммобілізації щурів спинкою донизу з інтервалом у 24 години (стрес 1) і 72 години (стрес 2) між окремими стресовими епізодами. Дослідження проводили через 24 години після останньої іммобілізації [11].

Усі експерименти проводили у першій половині дня в спеціально відведеному приміщенні при температурі $18-22^{\circ} \mathrm{C}$, відносній вологості $40-$ 60 \% і освітленості 250 лк. Досліди виконано з дотриманням норм Конвенції Ради Європи про захист хребетних тварин, що використовуються для досліджень та інших наукових цілей (Страсбург, 18.03.1986 р.), ухвали Першого національного конгресу з біоетики (Київ, 2001) і наказу МО3 України № 690 від 23.09.2009 р.

Для визначення морфологічних змін у серці робили поперечний зріз товщиною 0,4-0,5 cм на рівні обох шлуночків. Зрізи фіксували у 10 \% роз- 
Огляди літератури, оригінальні дослідження, погляд на проблему, випадок з практики, короткі повідомлення чині нейтрального формаліну. Готові зрізи зафарбовували гематоксиліном та еозином і розглядали під світлооптичним мікроскопом. Евтаназію щурів проводили шляхом тотального кровопускання з серця після попереднього тіопентал-натрієвого наркозу (60 мг·Кг $\Gamma^{1}$ маси тіла тварини внутрішньочеревно).

Результати й обговорення. При світлооптичному дослідженні поперечних зрізів сердець у всіх досліджуваних групах тварин, які зазнали впливу іммобілізаційного стресу, спостерігали незначні пошкодження міокарда, ступінь яких залежав від статі та моделі іммобілізаційного стресу. В усіх групах тварин виявлено помірний набряк як кардіоміоцитів, так і строми, різний ступінь некробіозу кардіоміоцитів та порушення мікроциркуляції.

При гістологічному дослідженні міокарда піддослідних ВГ самиць щурів, які зазнали стресу 1 (рис. 1), виявлено, що загальна структура його була збережена: м'язові волокна мали впорядковане розташування із добре вираженими анастомозами між ними.

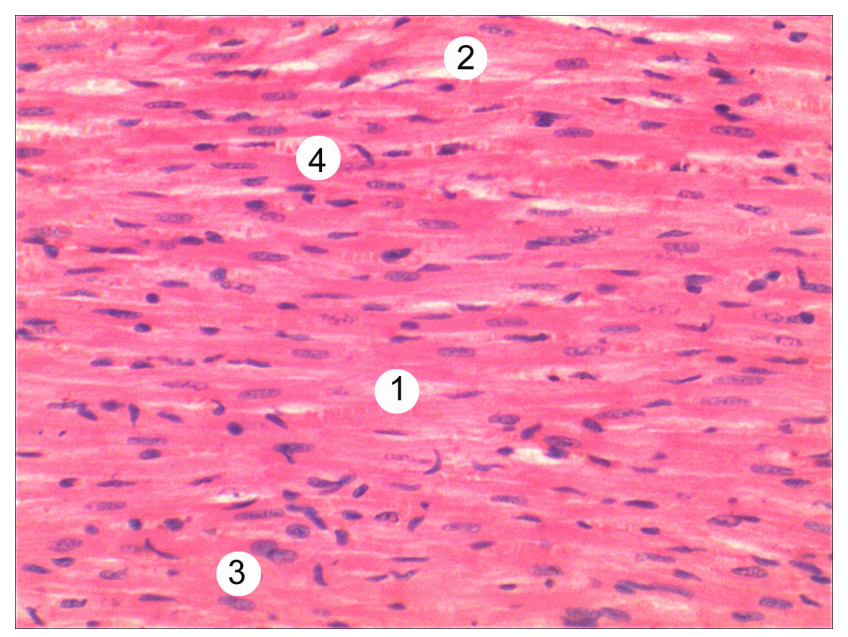

Рис. 1. Фрагмент міокарда високостійкого до гіпоксії щура-самиці, яка зазнала іммобілізаційного стресу 1.

Умовні позначення: помірний набряк кардіоміоцитів (1), незначний набряк строми (2), гіпертрофія ядер кардіоміоцитів (3), сладж-ефект еритроцитів (4). Забарвлення гематоксиліном та еозином. Збільшення $\times 200$.

Виявлено незначні деструктивні ураження м'язових волокон, порушення їх тинкторіальних властивостей, подекуди відмічено стази, було добре виражене кровонаповнення судин, в яких видно скупчення еритроцитів. З'являвся набряк кардіоміоцитів і строми. Скоротливі кардіоміоцити зберігали типову форму та розміщення. Еухроматичні ядра були переважно розташовані в центрі клітин і добре контурувалися на фоні нерівномірно просвітленої саркоплазми. Ці просвітлення мали вигляд вакуолей різних розмірів та інтенсивності за-

барвлення. У прошарках сполучної тканини між м'язовими волокнами подекуди добре вирізнялися фібробласти із великими еухроматичними ядрами та фіброцити невеликих розмірів із інтенсивно базофільними ядрами овальної форми. Подекуди виявляли також поодинокі малі лімфоцити. В окремих ділянках міокарда спостерігалася тинкторіальна неоднорідність кардіоміоцитів. Також було видно ділянки, в клітинах яких не проглядалося ядро, або воно було зміщене на периферію. Окремі волокна були набряклі.

У гістологічних препаратах сердець НГ самиць, які зазнали іммобілізаційного стресу 1, розширення компонентів мікроциркуляторного русла було вираженіше, вони мали більш дифузний характер, просвіти часто були заповнені значними скупченнями формених елементів крові (рис. 2).

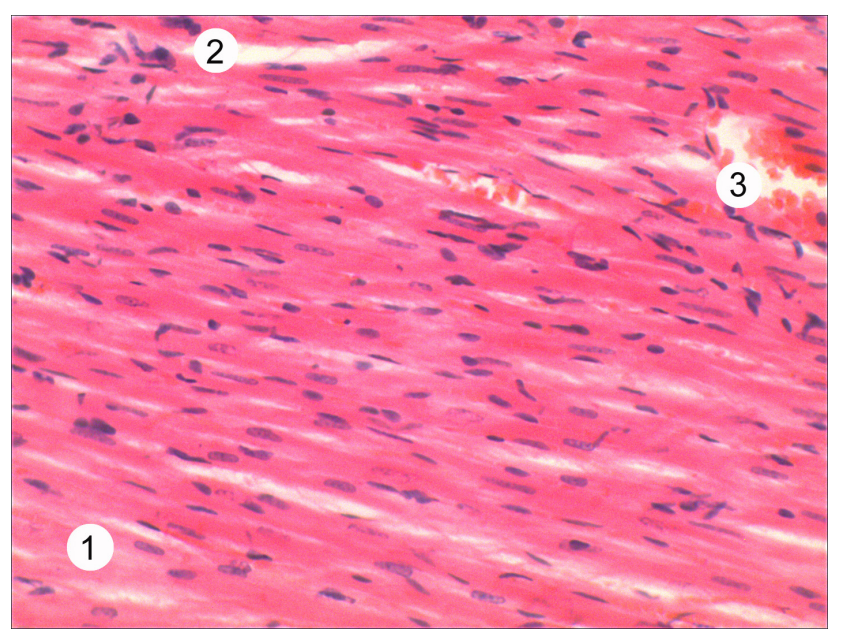

Рис. 2. Фрагмент міокарда низькостійкого до гіпоксії щура-самиці, яка зазнала іммобілізаційного стресу 1. Умовні позначення: просвітлення і набряк кардіоміоцитів (1), інтерстиційний набряк (2), розширення та кровонаповнення венули (3). Забарвлення гематоксиліном та еозином. Збільшення $\times 200$.

Периваскулярні простори були несуттєво розширені, дещо просвітлені. У них виявляли лімфоцити. У тварин були змінені скоротливі кардіоміоцити, у базофільних ядрах яких переважав гетерохроматин, порівняно із контролем. Відмічено розшарування м'язових волокон. Ядра суміжних клітин в окремих ділянках розміщувалися дезорганізовано. Набряк міофібрил і строми був вираженішим. Судини були розширені і кровонаповнені, у них відмічено адгезію та агрегацію еритроцитів. Слід зазначити, що у серцевому м'язі НГ самиць описані зміни були більшими, аніж у ВГ.

При розгляді препаратів міокарда ВГ щура самця, який зазнав іммобілізаційного стресу 1 , відмічено більші морфологічні зміни, ніж у ВГ самиць (рис. 3). 
Огляди літератури, оригінальні дослідження, погляд на проблему, випадок з практики, короткі повідомлення

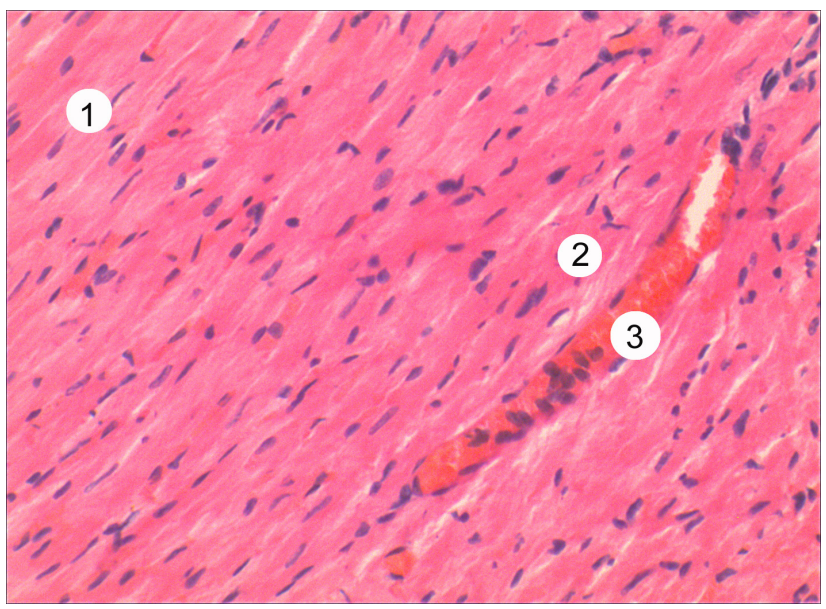

Рис. 3. Міокард піддослідного високостійкого до гіпоксії щура-самця, який зазнав іммобілізаційного стресу 1.

Умовні позначення: набряк кардіоміоцитів (1), деструкція кардіоміоцитів (2), кровонаповнення гемокапіляра (3). Забарвлення гематоксиліном та еозином. 36ільшення × 200 .

Скоротливі кардіоміоцити зберігали типову форму та розміщення, ядра були розташовані здебільшого на периферії клітини, контурувалися на фоні нерівномірно просвітленої саркоплазми. Особливим було те, що не у всіх кардіоміоцитах зміни виявилися тотожними: між вакуолізованими клітинами траплялися поодинокі клітини темнішого забарвлення із краще структурованою саркоплазмою. У прошарках сполучної тканини між м'язовими волокнами було видно фібробласти із великими еухроматичними ядрами та фіброцити невеликих розмірів із інтенсивно базофільними ядрами овальної форми. У міокарді спостерігалася тинкторіальна неоднорідність кардіоміоцитів. Також було видно ділянки, в клітинах яких ядро не проглядалося або воно було зміщене на периферію. Більшість волокон були набряклі, відмічено деструкцію кардіоміоцитів. У просвітах судин було видно неоднорідні скупчення формених елементів крові, лейкоцитарну інфільтрацію.

У НГ самців (рис. 4), які зазнали стресу 1 , зміни були найбільш виражені. Відмічено значне розширення елементів гемомікроциркуляторного русла та суттєве їх кровонаповнення, яке супроводжувалося виходом формених елементів крові за межі судинного русла.

Пошкодження в міокарді характеризувалися дрібновогнищевими ділянками змінених клітин, які місцями зливалися. Забарвлення саркоплазми таких кардіоміоцитів було нерівномірним. На фоні описаних змін виявлялися також гомогенні ділянки міокарда інтенсивного оксифільного забарвлення. Ядра клітин таких ділянок міокарда не візуалізувалися. Відмічені розволокнення кардіоміофібрил, стромальний набряк. Порушення

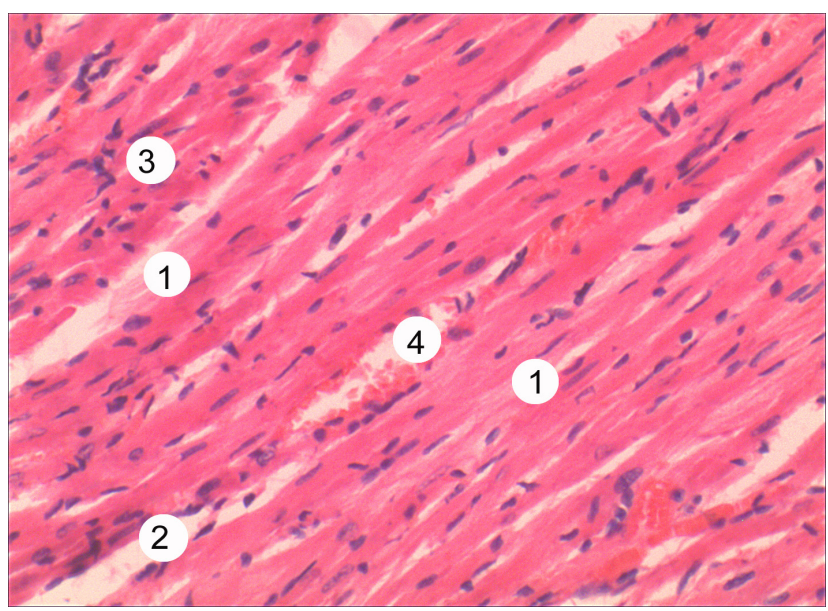

Рис. 4. Фрагмент міокарда низькостійкого до гіпоксії щура-самця, який зазнав іммобілізаційного стресу 1.

Умовні позначення: розволокнення міофібрил (1), набряк строми (2), деструкція кардіоміоцитів (3), розширений просвіт гемокапіляра (4). Забарвлення гематоксиліном та еозином. Збільшення × 200 .

тинкторіальних властивостей міокарда у НГ самців при стресі 1 були виражені найбільше.

При гістологічному дослідженні міокарда піддослідних ВГ самиць щурів, які зазнали стресу 2 (рис. 5), виявлено, що загальна структура його в основному була збережена: м'язові волокна мали впорядковане розташування, щоправда, анастомози між ними були добре виражені не всюди.

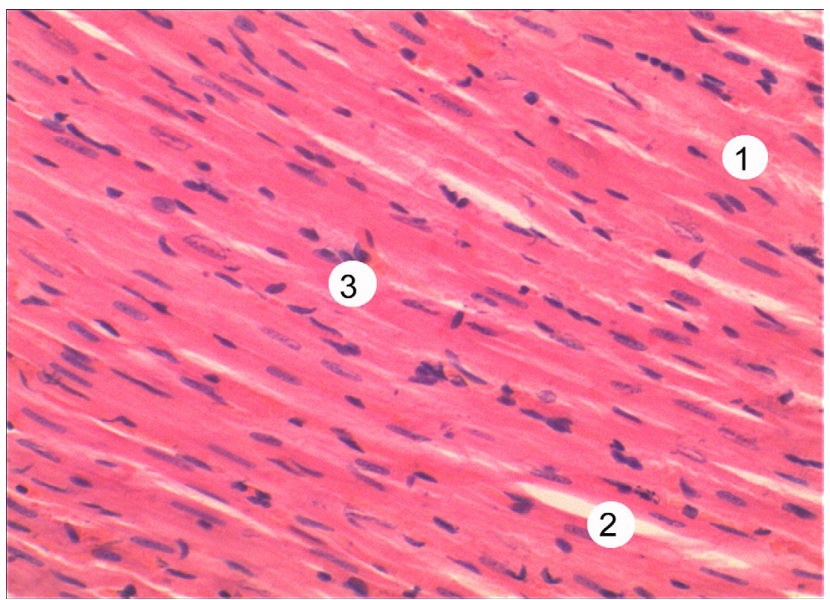

Рис. 5. Фрагмент міокарда високостійкого до гіпоксії щура-самиці, яка зазнала іммобілізаційного стресу 2. Умовні позначення: набряк кардіоміоцитів (1), помірний набряк строми (2), лейкоцитарна інфільтрація (3). Забарвлення гематоксиліном та еозином. Збільшення × 200 .

У прошарках сполучної тканини між волокнами було видно розширення елементів гемомікроциркуляторного русла. В їх просвітах спостерігалася незначна кількість формених елементів крові. Вищеописані ділянки вазодилатації розміщувалися вогнищево. Периваскулярні простори не відріз- 
Огляди літератури, оригінальні дослідження, погляд на проблему, випадок з практики, короткі повідомлення нялися від норми. Скоротливі кардіоміоцити зберігали типову форму та розміщення. В окремих ділянках міокарда спостерігалася тинкторіальна неоднорідність кардіоміоцитів. Також було видно ділянки, в клітинах яких не проглядалося ядро, такі місця мали неоднорідне забарвлення. Частина волокон була із помірним набряком. Відмічено набряк пухкої сполучної тканини. У полі зору було видно ділянки з лейкоцитарною інфільтрацією.

У гістологічних препаратах сердець НГ самиць, які зазнали іммобілізаційного стресу 2, тинкторіальна структура міокарда була порушена більше (рис. 6).

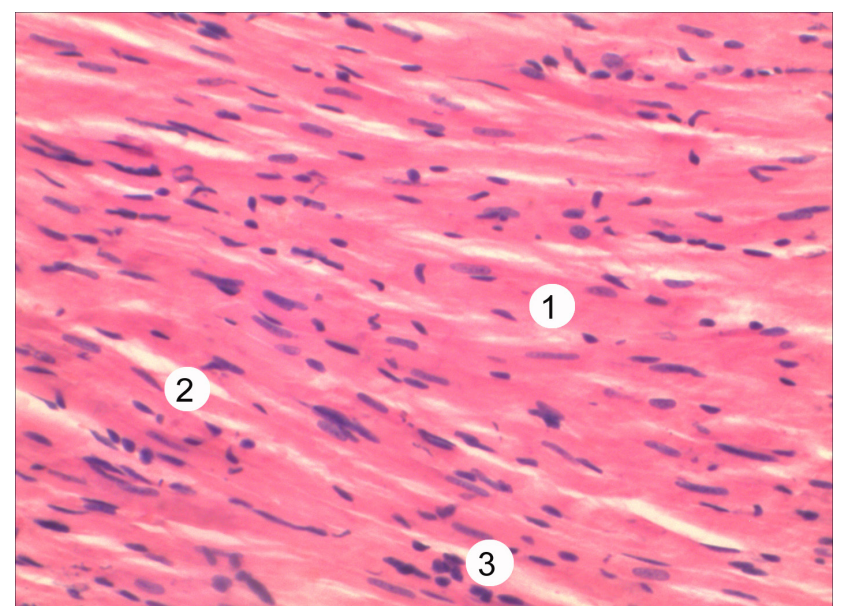

Рис. 6. Фрагмент міокарда низькостійкого до гіпоксії щура самиці, яка зазнала іммобілізаційного стресу 2. Умовні позначення: набряк і гомогенізація кардіоміоцитів (1), набряк строми тканини (2), лейкоцитарна інфільтрація (3). Забарвлення гематоксиліном та еозином. 36ільшення $\times 200$.

Відмічено розшарування м'язових волокон. У тварин була велика кількість змінених скоротливих кардіоміоцитів, у базофільних ядрах яких переважав гетерохроматин. Ядра суміжних клітин в окремих ділянках розміщувалися дезорганізовано. Розширення компонентів мікроциркуляторного русла були вираженіші, порівняно з ВГ, просвіти були заповнені скупченнями формених елементів крові. Периваскулярні простори були несуттєво розширені, дещо просвітлені, у них спостерігалися лімфоцити. Набряк міофібрил і їх гомогенізація були вираженими. Відмічені вогнища лейкоцитарної інфільтрації.

При розгляді препаратів міокарда ВГ щура самця, який зазнав іммобілізаційного стресу 2, були відмічені наступні зміни (рис. 7).

Просвіти гемомікроциркуляторного русла були заповнені форменими елементами крові. Скоротливі кардіоміоцити в основному зберігали типову форму та розміщення, ядра були розташовані переважно на периферії клітини, по різному контурувалися на фоні нерівномірно просвітленої саркоплазми. У міокарді спостерігалася тинкторіальна неоднорідність кардіоміоцитів, були ділянки, в клітинах яких не проглядалося ядро, або воно було зміщене на периферію. Волокна були набряклі.

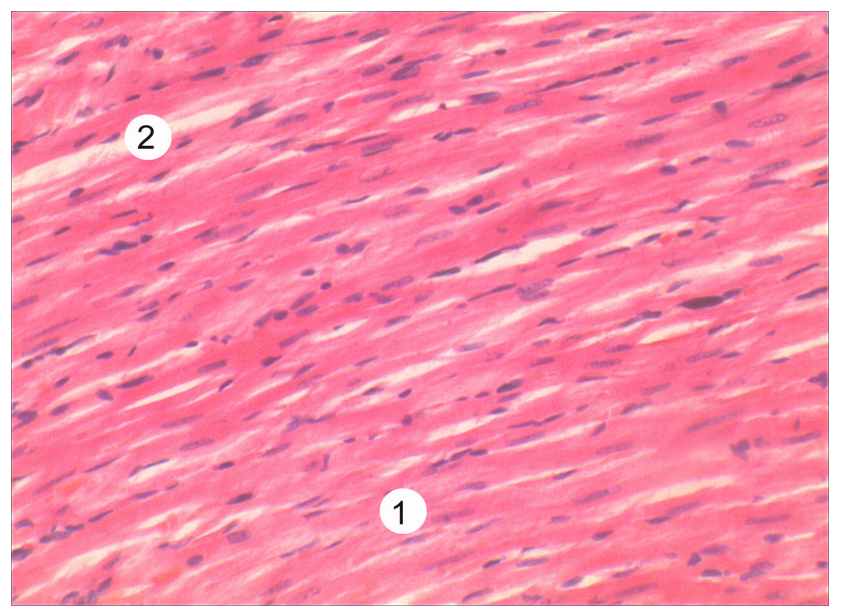

Рис. 7. Фрагмент міокарда високостійкого до гіпоксії щура-самця, який зазнав іммобілізаційного стресу 2. Умовні позначення: набряк кардіоміоцитів (1), набряк строми (2). Забарвлення гематоксиліном та еозином. Збільшення $\times 200$.

У НГ самців морфологічні зміни були найбільшими (рис. 8). Відмічено значне розширення елементів гемомікроциркуляторного русла та суттєве їх кровонаповнення, що супроводжувалося виходом формених елементів крові за межі судинного русла. В полі зору можна було побачити вогнища лімфогістіоцитарної інфільтрації. Пошкодження в міокарді характеризувалися дрібновогнищевими ділянками змінених клітин. Забарвлення сарко-

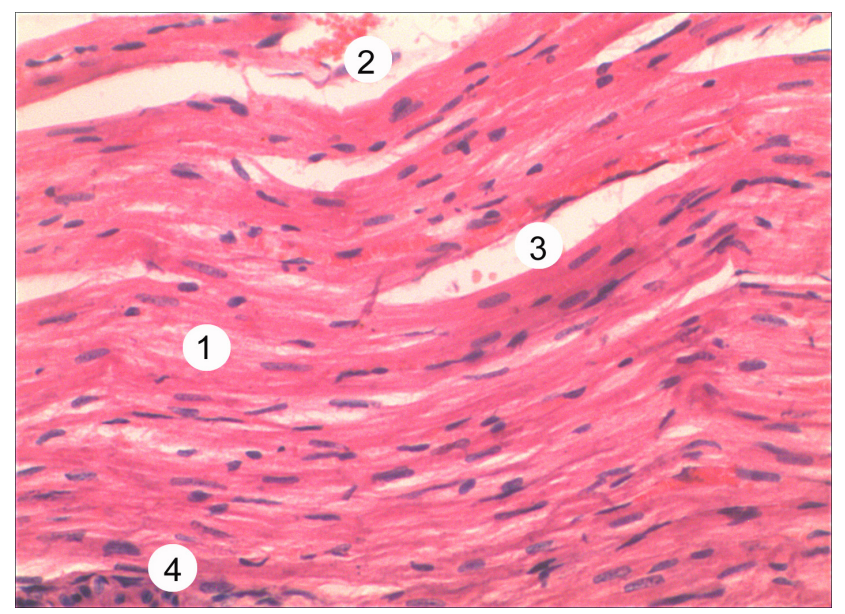

Рис. 8. Фрагмент міокарда низькостійкого до гіпоксії щура-самця, який зазнав іммобілізаційного стресу 2.

Умовні позначення: набряк і розволокнення міофібрил (1), діапедез еритроцитів (2), набряк строми (3), деструкція кардіоміоцитів (3), лейкоцитарна інфільтрація (4). Забарвлення гематоксиліном та еозином. 3більшення × 200. 
Огляди літератури, оригінальні дослідження, погляд на проблему, випадок з практики, короткі повідомлення плазми таких кардіоміоцитів було нерівномірним через її вакуолізацію. На фоні описаних змін виявлялися також гомогенні ділянки міокарда інтенсивного оксифільного забарвлення. Ядра клітин таких ділянок міокарда не візуалізувалися. Порушення тинкторіальних властивостей міокарда у НГ самців були виражені найбільше, відмічено розволокнення тканини міокарда.

Отже, у самців зміни були вираженіші, порівняно із самицями, а за стресу 2 - більші, ніж за стресу 1. Найбільші порушення виявлено у НГ самців.

Висновок. Інтервальна іммобілізація щурів призводить до порушення морфологічної структури міокарда, ступінь розвитку якого залежить від стійкості до гіпоксії, статі тварини та моделі стресу. Найбільше пошкодження виявлено при обох видах стресу в НГ самців.

Перспективи дослідження. Для з'ясування механізмів пошкодження за умов стресу потрібно провести аналіз вегетативного забезпечення серцевого ритму та морфологічне дослідження надниркових залоз.

\section{ЛІТЕРАТУРА}

1. Typological features of the nervous system of cows depending on the reactivity and stress resistance / L. V. Karlova, O. G. Gavrilina, N. V. Alekseeva, O. V. Peretyatko // Ukrainian Journal of Ecology. - 2018- No. 8 (2). P. 149-159.

2. Autonomic nervous system reactivity to positive and negative mood induction: The role of acute psychological responses and frontal electrocortical activity / W. J. Kop, S. J. Synowski, M. E. Newell [et al.] // Biol. Psychol. - 2011. - No. 86 (3). - P. 230-238.

3. Testosterone-cortisol dissociation in children exposed to prenatal maternal stress, and relationship with aggression: Project Ice Storm / T. V. Nguyen, S. L. Jones, G. Elgbeili [et al.]// Dev. Psychopathol.-2018.-No. 30 (3).P. 981-994.

4. Дорубець А. Д. Загальна імунологічна реактивність організму пацієнтів з малими дефектами зубних рядів / А. Д. Дорубець // Клінічна та експериментальна патологія. - 2016. - № 55 (1). - С. 59-62.

5. Children's stress regulation mediates the association between prenatal maternal mood and child executive functions for boys, but not girls / R. Neuenschwander, K. Hookenson, U. Brain [et al.]//Dev. Psychopathol.-2018.No. 30 (3). - P. 953-969.

6. Holm L. Influence of age, sex and seriousness on reporting of adverse drug reactions in Sweden / L. Holm,

\section{REFERENCES}

1. Karlova, L.V., Gavrilina, O.G., Alekseeva, N.V., \& Peretyatko, O.V. (2018). Typological features of the nervous system of cows depending on the reactivity and stress resistance. Ukrainian Journal of Ecology, 8 (2), 149-159.

2. Kop, W.J., Synowski, S.J., Newell, M.E., Schmidt, L.A., Waldstein, S.R., \& Fox, N.A. (2011). Autonomic nervous system reactivity to positive and negative mood induction: The role of acute psychological responses and frontal electrocortical activity. Biol. Psychol., 86 (3), 230-238.

3. Nguyen, T.V., Jones, S.L., Elgbeili, G., Monnier, P., Yu, C., Laplante, D.P., \& King, S. (2018) Testosterone-cortisol dissociation in children exposed to prenatal maternal stress, and relationship with aggression. Project. Ice Storm. Dev. Psychopathol., 30 (3), 981-994.

E. Ekman, K. Jorsäter Blomgren // Pharmacoepidemiol Drug Saf. - 2017. - No. 26 (3). - P. 335-343.

7. Children's Autonomic Nervous System Reactivity Moderates the Relations between Family Adversity and Sleep Problems in Latino 5-Year Olds in the CHAMACOS Study / A. Alkon, W. T. Boyce, T. B. Neilands, B. Eskenazi // Front Public Health. - 2017. - No. 5. - P. 155.

8. Пшенникова М. Г. Роль генетических особенностей организма в устойчивости к повреждающим воздействиям и в защитных эффектах адаптации / М. Г. Пшенникова // Патологическая физиология и экспериментальная терапия. - 2011. - № 4. - С. 7-16.

9. Зарубина И. В. Современные представления о патогенезе гипоксии и её фармакологической коррекции / И. В. Зарубина // Обзоры по клинической фармакологии и лекарственной терапии. - 2011. - № 8 (3). С. 31-48.

10. Березовский В. А. Гипоксия и индивидуальные особенности реактивности / В. А. Березовский. - К. : Наукова думка, 1978. - 216 с.

11. Кулинский В. И. Две адаптационные стратегии в неблагоприятных условиях: резистентная и толерантная. Роль гормонов и рецепторов / В. И. Кулинский, И. А. Ольховский // Успехи современной биологии. - 1992. - Т. 112. - С. 697-711.

4. Dorubets, A.D. (2016). Zahalna imunolohichna reaktyvnist orhanizmu patsientiv z malymy defektamy zubnykh riadiv [General immunological reactivity of the body of patients with small defects in dentition]. Clinichna ta experymentalna patolohiia - Clinical and Experimental Pathology, 55 (1), 59-62 [in Ukrainian].

5. Neuenschwander, R., Hookenson, K., Brain, U., Grunau, R.E., Devlin, A.M., Weinberg, J., Diamond, A., \& Oberlander, T.F. (2018). Children's stress regulation mediates the association between prenatal maternal mood and child executive functions for boys, but not girls. Dev. Psychopathol., 30 (3), 953-969.

6. Holm, L., Ekman, E., \& Jorsäter Blomgren, K. (2017). Influence of age, sex and seriousness on reporting of 
Огляди літератури, оригінальні дослідження, погляд на проблему, випадок з практики, короткі повідомлення adverse drug reactions in Sweden. Pharmacoepidemiol. Drug Saf., 26 (3), 335-343.

7. Alkon, A., Boyce, W.T., Neilands, T.B., \& Eskenazi, B. (2017). Children's Autonomic Nervous System Reactivity Moderates the Relations between Family Adversity and Sleep Problems in Latino 5-Year Olds in the CHAMACOS Study. Front Public Health, 5, 155.

8. Pshennikova, M.G. (2011) Rol geneticheskikh osobennostey organisma v ustoychivosti k povrezhdayushchim vozdeystviyem i v zashchitnykh effektakh adaptatsii [The role of genetic features of the organism in resistance to damaging effects and protective effects of adaptation]. Patologicheskaya physiologiya i experimentalnaya terapiya - Pathological Physiology and Experimental Therapy, 4, 7-16 [in Russian].

9. Zarubina, I.V. (2011). Sovremennye predstavleniya

o patogeneze gipoxii i ego farmakolgicheskoy korrektsii [Contemporary notions about the pathogenesis of hypoxia and its pharmacological correction]. Obzory po klinicheskoy farmakologii i lekarstvennoy terapii - Reviews on Clinical Ppharmacology and Drug Therapy, 8 (3), 31-48 [in Russian].

10. Berezovskyy, V.A. (1978). Gipoksiya $i$ individualnye osobennosti reaktivnosti [Hypoxia and individual particularities of reactivity]. Kyiv: Naukova dumka [in Russian].

11. Kulynskyy, V.I., \& Olkhovskyy, I.A. (1992). Dve adaptatsionnye strategii v neblagopriyatnykh usloviyakh: rezistentnaya i tolerantnaya. Rol gormonov i retseptorov [Two adaptation strategies in adverse conditions: resistant and tolerant. The role of hormones and receptors]. Uspekhi sovremennoy biologii - Advances of Modern Biology, 112, 697-711 [in Russian].

\title{
ВЛИЯНИЕ РАЗЛИЧНЫХ МОДЕЛЕЙ ИММОБИЛИЗАЦИОННОГО СТРЕССА НА МОРФОЛОГИЧЕСКИЕ ИЗМЕНЕНИЯ В СЕРДЦЕ ВЫСОКО- И НИЗЬКОУСТОЙЧИВЫХ К ОСТРОЙ ГИПОКСИЧЕСКОЙ ГИПОКСИИ КРЫС РАЗНОГО ПОЛА
}

\author{
○) О. В. Денефиль, Ю. Н. Ордынский, З. М. Небесная
}

Тернопольский национальный медицинский университет имени И. Я. Горбачевского МОз Украины

РЕзюМЕ. Стрессы случаются в нашей жизни ежедневно. На один и тот же стресс каждый человек реагирует по-разному и не задумывается о его последствиях для организма. Часто мы не учитываем повреждающего действия стресса на различные органы, в частности на сердечно-сосудистую систему. Определение механизма повреждающего воздействия стресса на сердце у лиц с различной реактивностью может способствовать разработке индивидуальных методов профилактики и коррекции.

Цель - определить влияние различных режимов иммобилизационного стресса на морфологические изменения в сердце крыс разного пола с высокой и низкой устойчивостью к гипоксии.

Материал и методы. Опыты выполнены на 96 высоко- и низькостойких к гипоксии крысах линии Вистар в возрасте 5,5-6 месяцев. Животных поделили на контрольные и исследовательские группы (подвергшиеся иммобилизационному стрессу). Стресс моделировали путем четырехкратной одночасовой иммобилизации крыс спинкой вниз с интервалом в 24 часа (стресс 1) и 72 часа (стресс 2) между отдельными стрессовыми эпизодами. Исследование проводили через 24 часа после последней иммобилизации.

Результаты. При светооптическом исследовании поперечных срезов сердец во всех исследуемых группах животных, подвергшихся воздействию иммобилизационном стресса, наблюдали незначительные повреждения миокарда, степень которых зависела от пола животного и модели иммобилизационного стресса. Во всех группах животных обнаружены умеренный отек как кардиомиоцитов, так и стромы, разная степень некробиоза кардиомиоцитов и нарушения микроциркуляции. При стрессе 1, по сравнению со стрессом 2, степень поражения миокарда была меньшей. У ВГ животных, по сравнению с НГ, повреждения были выражены слабее. Наибольшие изменения произошли при обоих видах стресса у низькостойких к гипоксии самцов.

Вывод. Интервальная иммобилизация крыс приводит к нарушению морфологической структуры миокарда, степень развития которого зависит от устойчивости животных к гипоксии, пола и модели стресса. Больше повреждений отмечено при обоих видах стресса у нискостойких к гипоксии самцов.

КЛЮЧЕВЫЕ СЛОВА: стресс; крысы; резистентность к гипоксии; сердце, морфологические изменения.

\section{THE INFLUENCE OF DIFFERENT MODELS OF IMMOBILIZATIONAL STRESS ON MORPHOLOGICAL CHANGES OF HIGH AND LOW-RESISTANCE TO ACUTE HYPOXIC HYPOXIA RATS OF DIFFERENT SEX}

๑O. V. Denefil, Iu. M. Ordynskyi, Z. M. Nebesna

\section{Horbachevsky Ternopil National Medical University}

SUMMARY. Stress is encountered daily in our lives. Everyone responds differently to one and the same stress, and does not think about its consequences for the body. Often, we do not take into account the damaging effects of stress on various organs, and in particular, the cardiovascular system. Determining the mechanisms of damaging the influence 
Огляди літератури, оригінальні дослідження, погляд на проблему, випадок з практики, короткі повідомлення of stress on the heart in people with different reactivity can contribute to the development of individual methods of prevention and correction.

The aim of the study - to determine the effect of various modes of immobilization stress on morphological changes in the heart of rats of different sex with high and low resistance to hypoxia (HR, LR).

Material and Methods. In the experiment on 144 Wistar line rats (72 males, 72 females) morphological changes of heart were determined. The animals were divided into three groups - control and two experimental (who have under the immobilization stress). Stress was modeled 4 times by a one-hour immobilization of the rats on the back with an interval of 24 hours (stress 1 ) and 72 hours (stress 2). The studies were carried out 24 hours after the last immobilization.

Results. In a light-optical study of transverse sections of rats' hearts, in all study groups of animals exposed to immobilization stress, minor damage to the myocardium was observed, the degree of which depended on the resistence to hypoxy, sex and the model of immobilization stress. In all groups of animals, moderate swelling of both cardiomyocytes and stroma, a different degree of necrobiosis of cardiomyocytes and microcirculation disorders were detected. In stress 1, compared with stress 2, the degree of myocardial damage was less. In HR animals, in comparison with LR, the damage was less pronounced. Major changes were noted for both types of stress in males.

Conclusions. Interval immobilization of rats leads to a violation of the morphological structure of the myocardium, the degree of development of which depends on resistance to hypoxia, sex and stress patterns. The greatest damage was observed in both types of stress in males.

KEY WORDS: stress; rats; resistance to hypoxia; heart; morphological changes. 